\title{
The Ancient Tombs of Nicaragua
}

\section{Frederick Boyle F.R.G.S.}

To cite this article: Frederick Boyle F.R.G.S. (1866) The Ancient Tombs of Nicaragua, Archaeological Journal, 23:1, 41-50, DOI: $\underline{10.1080 / 00665983.1866 .10851339}$

To link to this article: http://dx.doi.org/10.1080/00665983.1866.10851339

曲 Published online: 11 Jul 2014.

Submit your article to this journal 주

Q View related articles $\square$ 


\section{THE ANCIENT TOMBS OF NICARAGUA.}

By FREDERICK BOYLE, F.R.G.S.

AT the date of its subjugation, A.D. 1526, Nicaragua was peopled by at least three distinct Indian races, and, even to the present day, in wandering through the less settled districts, the traveller may trace among the inhabitants those peculiar features which characterised each of those families. These broad divisions appear to have been-firstly, the Toltec or Chorotegan, here, as elsewhere, claiming to be the aboriginal possessors of the country ; secondly, the Chontal ; and thirdly, the Carib. There seems good reason also to believe that a colony of veritable Astecs was located upon the territory lying between the Lakes and the Pacific; these people were called Niquirans, and spoke the Mexican tongue. The Toltecs inhabited the northern country from the Pacific coast to the mountains of Chontales, and south of the lakes into Costa Rica; the Chontals occupied the province still called by their name; and the Caribs, a more barbarous but also more spirited people, under various names and with much diversity of dialect and habit, were thinly scattered along the Atlantic shore. All accounts agree that, when the Spaniards entered the country, they found a population so dense as to excite their amazementcities, we are told, four Spanish leagues in length-a people most active and industrious, and a soil and climate beyond their utmost expectations. The soil and climate still remain unchanged, but the most hopeful traveller could find little else in modern Nicaragua to correspond with Oviedo's account of its ancient prosperity.

By each of the three races the disposal of the dead was differently conducted. The Chontals, a mountainous people, seem to have used cremation and interment indifferently, but in either case the remains were finally deposited upon the summit of a hill, or in an artificial mound upon the broad savannah. Over the body was raised a cairn of rough stone, the size of which varied exceedingly.

VOL. XXIII. 
Of the Caribs we know little, but, as their habits have probably not changed in one iota since the Spaniards conquered the neighbouring country, it seems likely that they buried their dead with little ceremony, and marked the spot with a parallelogram of small stones. Old graves such as these we remarked once or twice in the border-land of Chontales, and such is a frequent practice among the Indian tribes of Mosquito.

The Toltec graves are much more difficult to find than those of the Chontals. Indeed in the ancient seats of that people round the Lake of Nicaragua, it is only by accident that their last resting-places are occasionally disclosed; and those numerous graves upon the frontier line of Costa Rica, which have lately afforded so many valuable specimens of Indian art and ingenuity, were accidentally revealed by the fall of a large tree, the roots of which, tearing away a piece of the river bank, laid bare a considerable quantity of golden figures deposited in the earth. Tradition says that the Toltecs burnt the flesh of the deceased and buried the bones, or some of them, in pots of earthenware, and this story is confirmed by the appearance of their graves.

A similar practice appears to have been in use among the inhabitants of Ometepec, whom Mr. Squiers asserts to hare been of the Niquiran race. On that island, however, rarely are any bones found except those of the skull.

In riding through the broad savannahs and over the green and rounded hills which are characteristic of the old Chontal territory, the traveller cannot but be struck with the picturesque appearance of the lonely thickets which spring up at long intervals above the grassy waste. These solitary little groves are always found to have root in a cairn of loose rocks in the form of a parallelogram, and sometimes of immense size. The largest that we measured was 58 yards long by 40 wide, and the smallest $20 \mathrm{ft}$. by 8 ; in height they vary from 10 to $4 \mathrm{ft}$. The majority of them have been more or less overthrown by the growth of great trees, but some are still in sufficient preservation to show how careful was the original building. The sides were sometimes sloped, or, more rarely, quite straight, but in either case a low parapet of rough stone was placed along the edge. On every one are found either the fragments of 
statues and sculptured bits of pedestal, or at least the deep holes in which they had been planted. Some of these figures have been overthrown quite recently, but ages ago all suffered terrible mutilation from the superstitious zeal of the Spaniards. So far as we could ascertain a small statue was placed at each corner of the cairn, and a much larger one was planted with more or less accuracy in the centre. Occasionally there were several of the central figures, and it is probable that they corresponded with the number of bodies interred. The position of these monoliths is the only clue hitherto discovered to guide the digger in his search through the vast pile of stone, but very frequently his calculation proves completely erroneous.

Looking at the situation of these statues thus placed above the deceased, and observing the human character that exists about most of them; the careful delineation of the features (in some cases very peculiar); the attempt of the artist, apparent to me, to imitate minutely some object before his eye as he worked, it is difficult to avoid a suspicion that they were intended as imperishable portraits of the dead. I would particularly call attention to two specimens, which were central figures on a small cairu we opened. Broken and defaced as they are, they still give a very fair idea of a grim old warrior and his more amiable spouse. In two others there are noticeable peculiarities, which are scarcely godlike though human enough; one of them has a large wen over the eye; the other, though battered out of all shape as to his features, still displays the long curl of his beard and whiskers almost uninjured; and such manly ornaments, though rare, are occasionally met with among Indians. Indeed if anyone will compare these statues from Chontales with those found in Toltec or Niquiran districts, he cannot fail to remark a radical difference, not in the style of art merely but in the idea of the artist. From these and some other observations we made, which would not be strictly in place in this memoir, we formed a strong suspicion that 'I'orquemada and Las Casas are wrong in asserting that the religion of all the Nicaraguan Indians was identical.

The first cairn that we opened was near the mining town of Libertad, in the north east of Chontales. It was of the largest dimensions, being 58 yards long by 40 broad, and stood on the summit of a mound some 60 or $70 \mathrm{ft}$. high. 
Several treasure-seekers had already sunk random shafts into its solid construction, but without success. Selecting as nearly as possible the centre of the cairn, and encouraged by the discovery of a massy fragment of sculpture which stood erect above the spot, we set to work patiently in removing the stones. The previous attempts were of great service to us, and after little more than an hour's labour we came upon a carved flat stone, such as is still used throughout Spanish America for the grinding of maize. The rollingpin belonging to it lay by its side. After two hours more of tedious labour we found another similar stone lying due east of the former. Then we uncovered two pans of coarse earthenware, about 4 in. in height by 7 in diameter. They were placed close together by the side of the "molinera," but the vast mass of rock in settling down had broken them irretrievably; there was no perceptible trace of any contents. Shortly after, and still parallel to the line of the "molineras," we found a vase of soft stone, subsequently ascertained to be a species of marble, also shattered to pieces. For two days more we laboured, but with no success.

The second cairn that we attacked was considerably smaller, but built with great regularity and having the coping-stones nearly perfect. Determined to investigate this tomb most thoroughly, we set our labourers to throw down the whole pile, which was the more easy as it crowned the summit of a very steep hill, and was not more than $4 \frac{1}{2} \mathrm{ft}$. thick. For four days we persevered in our task, having never less than three men at work from early morning to nightfall, and sometimes the labourers were six or seven in number. On the fifth day we had cleared away about a sixth part of the cairn, working in a line from the eastern corner towards the centre. On the sixth morning we commenced to dig in the cleared ground, but until sunset found nothing. The earth was turned over to the depth of $2 \mathrm{ft}$., and our experienced workmen assured us that remains had never been found so far beneath the surface. At dusk we were about to abandon the "prospect" in despair after six days of continuous labour, when we suddenly came upon a "molinera" stone, such as those encountered in the former cairn. Next morning we dug out another vase of white marble, much broken, but superior to the frist in design. It was in shape 
like a can resting on a perforated stand, and profusely carved on the sides. An ornament, perhaps originally a handle, stood out from each side. Next we came upon a quantity of crockery, crushed flat but apparently similar in shape to the pan-like vessels found in the same position in the other cairn, and again there was no trace of contents. Then we discovered a great quantity of human teeth, sufficient probably for half-a-dozen individuals, and shortly afterwards a row of cinerary urns, about $20 \mathrm{in}$. high and 15 in diameter, lying east and west. They were five in number, and it seemed probable that through their crushed sides had fallen the teeth just discovered. They all contained the sticky black earth, quite different from the surrounding soil, which we concluded to be the remains of burnt flesh, but no bones or other articles. Our researches produced nothing further.

It is very rarely that these Chontal tombs are opened. The labour is intense, the surrounding population is very poor and not the least inclined towards archæology, and the reward of a spirited digger is very small. I cannot believe, although it is contrary to the received opinion, that any of the Nicaraguan Indians were in the habit of burying gold with their dead; but the tribes of Honduras to the north and of Costa Rica to the south both practised it largely. A rattle of washed gold, which we dug up in a cinerary urn near Juigalpa, is the only article of metal we could hear of which had been indubitably discovered in that province ; the grave also from which we recovered this relic and its accompanying necklace was by no means Chontal in appearance. Oviedo, Torquemada, Herrera, and all the early writers, refer frequently to the golden ornaments and the copper instruments of the Indians ; but it is probable that they drew little distinction between the country now called Nicaragua and the neighbouring states of Costa Rica and Honduras, the inhabitants of which have left abundant proof of their superior civilisation in the numerous and valuable articles deposited with their dead.

In the cairns of Chontales are sometimes found axes and celts of stone-flint or basalt ; flakes of flint occasionally in small quantities ; nearly always a considerable pile of broken crocks, which never apparently contained anything ; and invariably one or two molineras or maize grinding-stones. Many of these are handsomely carved in a style superior to 
anything now produced in the country, and some of the stone weapons are admirably modelled. At libertad a doublebladed battle-axe was offered us for sale, which for accuracy of form and beauty of workmanship more than equalled anything of the kind I have seen in Europe. The owner of this instrument was fond of opening the small cairns which exist in thousands around Libertad; but he told us that he had rarely discovered any perfect pottery and never any articles of metal. Persistently, however, he asserted the truth of a report which had first called our attention to this district of Chontales, viz., that it was no unusual thing there to dig out fragments of porcelain or of some similar composition from the larger graves. It did not occur to us at the moment that the vases of white stone, such as we ourselves had discovered, might be the porcelain alluded to.

In cases where the body has not been burned, the bones are found mingled with the stones of the cairn above the surface of the ground. It is in graves such as these that weapons are more usually disinterred.

The density of population in ancient Nicaragua, especially on the shores of the Lake, is abundantly proved by the quantity of broken pottery which everywhere can be dug up a few inches below the ground. Wherever a hole is made, there a fragment of some antique vessel is sure to be found, either a grotesque mask, or the leg of a tripod, or a stone rattle such as was used in the religious ceremonies of the Indians. In the middle of the prairie, in the thickest jungle, on the mountain side, or in the sandy beach, everywhere this is the case, but most notably so in the island of Ometepec in the Lake of Nicaragua.

Through ignorance of the exact boundaries of these ancient tribes I am unable to venture on any theory as to whether Toltecs or Niquirans were the early inhabitants of this island, but its name, Ome-Tepec, is undoubtedly Mexican. Whether Toltec or Niquiran, however, these people, probably owing to their island position and consequent immunity from sudden attack, seem to have made great progress in art, and to have formed a population comparatively more dense than even the thickly peopled mainland. From Ome-Tepec almost all the antiquities hitherto furnished by Nicaragua have been procured; here stood, until a few years since, the best carved and most gigantic monoliths. On the sister island of Zapa- 
tero, once crowded with Indians, but now uninhabited, are still to be seen numerous idols in the very first style of grotesque horror.

Antiquities are most numerous and in best preservation on the south-western slope of Ometepec. I am to be understood literally in saying that the inhabitants of that district depend entirely on their spades for their domestic pottery. Partly from shame and partly from a feeling of awe, they are most jealous of any allusion to the history or language of their ancestors; but a tradition is still extant among them, the only one in fact which we could gather, that when the news of the Spanish conquests on the mainland was spread abroad, so great was the terror already everywhere felt from the reports of their cruelty, that the Indians all buried themselves alive with their household goods, and the conquerors were compelled to repeople the island. As regards the concealment of property this story seems likely enough, for, of the deposits almost daily uncovered by persons in search of some basin or crock for the wants of their primitive housekeeping, many it is quite clear have no connection whatever with any burial. The Indians know at a glance, by the position of the crocks, whether they may expect to find therein some mouldering bones of their ancestors, or whether, without scruple of conscience, the treasure may at once be turned to account. If the deposit be funereal, the earthenware is found piled up in a single heap ; if otherwise, it is scattered about without order.

The ashes of the dead, with the bones of the skull, were placed in an urn of slipper shape; the beads of basalt or calcedony, the celt, or the flakes of flint were placed among them; in the mouth of the urn were laid the basins of black earthenware, the larger overlying the smaller; and over all were placed bowls of whitish glaze, covered with odd markings, which closed the mouth. Some of these cinerary urns are of great size. We have met with them $3 \mathrm{ft} .1 \mathrm{in}$. in length and $20 \mathrm{in}$. high ; they are nearly always painted in streaks of scarlet and black, with an ornament of two or three snakes upon the rounded end. At the back is frequently a grotesque mask or handle attached with "slip," or some similarly adhesive material. Occasionally the urn is more bowl-like in form; of such $I$ have seen two specimens, one of which, used by the finder as a horse-trough, was $2 \mathrm{ft} .10 \mathrm{in}$. 
in height by $2 \mathrm{ft}$. $6 \mathrm{in}$. in diameter in the centre. It was painted in streaks of scarlet and black.

None of the inhabitants of Nicaragua appear to have been hunters. Though deer abound throughout the country, and peccaries, pumas, tapirs, maniti, and other animals, are all numerous, those trophies of skill and daring so much valued by our ancestors - the boar's tusk, the deer's horn-are never found in Indian graves. Even the bones of animals are not common. The alligator is a frequent ornament of their pottery and statues, and I once found in the jungle a rude clay representation of a stag, but the human face, grotesquely distorted, was the usual model of their artists. Glass does not appear to have been known to them, nor the use of any metal. It is true that the Cacique of Rivas is said by Peter Martyr to have presented D'A vila with gold to the value of twenty-five thousand pieces of eight; but, as already stated, we were assured by all persons of any experience that in no part of Nicaragua were gold ornaments found, and I should prefer to believe that $D^{\prime} A$ vila spread reports of such wealth to draw the attention of the adventurous to the scheme of colonisation he was at that time meditating. Mr. Squiers in his work upon this country presents an engraving of a copper mask from Ometepec, but, in the absence of further specimens, the antiquity of this relic must appear doubtful. We are expressly told that the Indians fought against their invaders with arms of wood and stone; surely in a country so wonderfully rich in copper, that metal, had the people possessed any knowledge of working it, must in a very few years have superseded wood and stone for purposes of war. Such indeed we find to have been the case in Costa Rica and New Granada, but in Nicaragua, except here and there a solitary article such as the rattle I have alluded to-which may have been brought from another country by a fugitive or prisoner of war-no trace of any such knowledge is to be found in their graves. The Indians themselves also at this day are unanimous in ascribing to the Spaniards their first instruction in the use of metal.

In conclusion I would venture to remind any member of this Society who may have a liking for adventurous research, of the wonderful prospect that Central America offers to the antiquary. Besides the stone enigmas of Pillenque and Copan, the mysterious romance of the Maya city-the true 
story of which is by no means so absurd as we are used to believe in England-besides the treasures which lie buried in the graves on the Serebpiqui, there are, if we may believe report, dead cities of far greater size and splendour than any yet known. In the wild Mosquito territory are vast remains of a civilisation long passed away. Sometimes, on the lonely shores of the Mico, amidst the unstayed vegetation of a thousand years, the startled traveller is brought face to face with works of such magnitude, sculptures of such colossal boldness, as tell him of a perished race as far superior to that the Spaniards found as the builders of Thebes to the Nile "fellaheen." He sees rocks cut down to the shape of men and animals; artificial hills encased in masonry; streams turned from their courses; volumes of hieroglyphics sculptured upon every cliff. Or, turning to the southwardthere, across the San Juan river, dwells that mysterious and dreaded people the Guatusos or White Indians of the Rio Frio. This strange and indomitable race, who may possibly owe their bravery and love of freedom to an ancestry of English buccaneer's, occupy the north east corner of Costa Rica, and there, surrounded by settled country, within three weeks of direct sail from England, they positively keep the wealthiest district of that Republic as completely closed to the world as if it were sunk beneath the Atlantic. What stories have we not heard of them from Caribs and Indians? What tales of wonder are too wild for belief when they relate to the country of the dreadful Guatusos?

For various reasons of self-interest the oligarchical government of Costa Rica has hitherto set itself most decidedly against any endeavour to penetrate the territory of these fierce savages, or to enter into communication with them, but Dr. Castro, who has been recently made President, expressed to us, on the day of his election, a hope that the mysteries of the Rio Frio might soon be solved. But, if this anticipation is to be realised, it must be by foreigners. There is nothing to be expected from the natives of the country.

It is my intention to renew, in the ensuing spring, the attempt that I have recently made to explore the Rio Frio district, so replete with remarkable and stirring interest. To ensure the success of an undertaking fraught with difficulty and danger, as such an adventure must prove, it would,

VOL, XXIII. 
however, be indispensable to secure a few energetic and spirited auxiliaries, such as are doubtless to be found in the ranks of a society so devoted to the investigations of bygone times and extinct races as the Institute. It would be necessary that such an enterprise should be combined independently, for the most part, of the people of Costa Rica, whose hesitation and timidity-notwithstanding that they have such a vital interest in the exploration-caused the failure of the expedition recently organised by myself in concert with Mr. Jebb. The importance of the Rio Frio and of the country inhabited by the Guatusos cannot be overrated, in regard to its historical and ethnological interest. I cherish the hope that the wishes so cordially expressed by the late President of the Institute, the late Marquess Camden, and by other influential members of the Society, that adrenturous coadjutors might be found ready to give efficient cooperation in the arduous enterprise on which I purpose next year to engage, may be fully realised. 